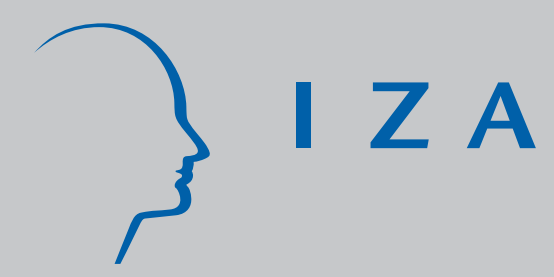

IZA DP No. 1720

The Existence and Persistence of Long Work Hours

Robert Drago

David Black

Mark Wooden

August 2005 


\title{
The Existence and Persistence of Long Work Hours
}

\author{
Robert Drago \\ Pennsylvania State University \\ David Black \\ Melbourne Institute of Applied Economic and Social Research, \\ University of Melbourne \\ Mark Wooden \\ Melbourne Institute of Applied Economic and Social Research, \\ University of Melbourne and IZA Bonn
}

\section{Discussion Paper No. 1720 \\ August 2005}

\author{
IZA \\ P.O. Box 7240 \\ 53072 Bonn \\ Germany \\ Phone: $+49-228-3894-0$ \\ Fax: +49-228-3894-180 \\ Email: iza@iza.org
}

\begin{abstract}
Any opinions expressed here are those of the author(s) and not those of the institute. Research disseminated by IZA may include views on policy, but the institute itself takes no institutional policy positions.

The Institute for the Study of Labor (IZA) in Bonn is a local and virtual international research center and a place of communication between science, politics and business. IZA is an independent nonprofit company supported by Deutsche Post World Net. The center is associated with the University of Bonn and offers a stimulating research environment through its research networks, research support, and visitors and doctoral programs. IZA engages in (i) original and internationally competitive research in all fields of labor economics, (ii) development of policy concepts, and (iii) dissemination of research results and concepts to the interested public.
\end{abstract}

IZA Discussion Papers often represent preliminary work and are circulated to encourage discussion. Citation of such a paper should account for its provisional character. A revised version may be available directly from the author. 


\section{ABSTRACT \\ The Existence and Persistence of Long Work Hours*}

Previous research hypothesizes that long working hours are related to consumerism, the ideal worker norm, high levels of human capital, and a high cost-of-job-loss. The authors test these hypotheses using panel data on working hours for an Australian sample of full-time employed workers. Analyses include a static cross-sectional model and a persistence model for long hours over time. The results suggest that long hours (50 or more hours in a usual week) are often persistent, and provide strongest support for the consumerism hypothesis, with some support for the ideal worker norm and human capital hypotheses, and no support for the cost-of-job-loss hypothesis. Other results are consistent with a backward-bending supply of long hours, and with multiple job holders and the self-employed working long hours.

JEL Classification: J22

Keywords: HILDA Survey, overwork, working hours

Corresponding author:

Mark Wooden

Melbourne Institute of Applied Economic and Social Research

Alan Gilbert Building

University of Melbourne VIC 3010

Australia

Email:m.wooden@unimelb.edu.au

\footnotetext{
* This paper uses the confidentialised unit record file (release 3.0) of the Household, Income and Labour Dynamics in Australia (HILDA) survey. The HILDA Survey project was initiated and is funded by the Australian Department of Family and Community Services (FaCS) and is managed by the Melbourne Institute of Applied Economic and Social Research. The findings and views reported in this paper, however, are those of the authors and should not be attributed to either FaCS or the Melbourne Institute.

The authors also thank the Australian Research Council and the Faculty of Economics and Commerce, University of Melbourne, for its financial support of this research, and Bruce Headey and Forrest Briscoe for valuable comments.
} 


\section{Introduction}

A debate concerning overwork, sparked by Juliet Schor's Overworked American (1991), ultimately concluded that working time in the U.S. had become more divided in recent decades, with larger proportions of individuals working either very long or very short hours (see Jacobs and Gerson 2004). Similar trends have been reported in some other countries, especially the U.K. (Harkness 1999) and Australia (Wooden 2001). Indeed, Jacobs and Gerson (2000) identified Australia, despite its much higher incidence of part-time employment, ${ }^{1}$ as one country where the proportion of the workforce reporting working 50 hours or more per week exceeded that in the U.S.

Analyses of the effects of long hours sometimes find linkages between long hours and, for example, stress and fatigue (Sparks et al. 1997). Other studies report mixed results (Barnett 1998). What we know with more certainty is that individuals who occupy multiple life roles tend to experience better mental health outcomes (Barnett 1998; Barnett and Rivers 2004) and, of course, regularly working very long hours, by reducing the time available for other activities, limits the ability of an individual to fill multiple roles.

If very long work hours were temporary, there might be no cause for concern. For example, if individuals were able to vary working hours as dictated by turns in the life course, long work weeks might be acceptable and even desirable at times (Moen and Roehling 2004). Therefore, analyses viewing long hours as a source of social and individual concern involve an implicit presumption that overwork is persistent. The presumption of persistence is clear in Schor's (1991, 1999) arguments regarding the "work-and-spend" cycle, as well as in Williams' (1999) treatment of the "ideal worker" as a careerist who works long hours for years or even decades at a stretch. Despite this, there have not been any empirical studies which have examined the extent to which long work hours persist over time. A number of studies have used cross-section or ethnographic data to report on the factors associated with long hours working at a single point in time (e.g., Schor 1991; Hochschild 1997; Jacobs and Gerson 2000, 2004; Moen and Roehling 2004), but so far researchers have neither quantified the likelihood of a worker continuing to work long hours in the future nor attempted to ascertain whether the correlates of persistent long hours differ from those found in crosssection analyses. Both tasks are performed here.

Specifically, this paper first reviews different theories that might explain why so many workers tolerate long working hours. We then use panel data collected from a nationally 
representative sample of Australian employees to test these different explanations. First, we estimate cross-sectional probit models of the factors associated with long work hours using two alternative definitions of long hours based on the number of usual weekly hours - 50 or more and 60 or more. Second, we exploit the panel nature of the data and estimate an ordered probit model of persistence in long working hours. Our results confirm the importance of both persistence in long work hours and of explicitly modeling persistence when analyzing the factors associated with long hours.

\section{Theories of Long Hours}

A variety of theoretical considerations can help to explain long work hours. Except as noted below, these considerations are mainly independent of each other, and hence each might help to explain the phenomenon.

Consumerism. Schor (1991, 1999) argued that corporations generate increased revenues by expanding the range or goods and services considered part of a usual or at least desirable standard of living. Larger houses, cable television, home entertainment systems, cellular phones, designer clothes, and expensive cars have, for example, all become more common in the U.S. As a result, many Americans, mainly in the top half of the income distribution, may be caught in a "work-and-spend” cycle. In order to purchase new commodities, individuals and families seek higher incomes, and for most that implies longer work hours. These longer hours must then be sustained over time to maintain expenditure patterns. In addition, families may take on substantial amounts of debt in order to fund consumer purchases, further driving the persistence of long hours to cover debt payments. We therefore hypothesize that increasing levels of debt, and particularly consumer debt, will be associated with long and particularly persistently long hours.

Ideal worker norm. A variety of researchers have argued that an ideal worker norm has spread among professionals such that relevant individuals expect themselves and others in similar positions to work long hours, with few breaks for holidays or vacations, for periods of years or even decades at a stretch (Bailyn 1993; Hochschild 1997; Williams 1999; Blair-Loy 2003; Jacobs and Gerson 2004; Moen and Roehling 2004). The ideal worker norm has several aspects, including behavior, expectations, and promotion and reward structures. Behaviorally, the ideal worker holds a career position, puts in long hours, is unencumbered by family commitments, and is prepared to relocate for career advancement. For example, Williams (1999) documents these high levels of commitment behaviors among lawyers, 
accountants, managers, and academics. Moen and Roehling (2004), looking over the lifecourse, find the norm involving a continuous pattern from higher education to career to retirement. As a norm, the ideal worker implies that individuals in relevant careers expect others and themselves to engage in ideal worker behavior; departure from lockstep commitment to career is viewed as deviance and therefore penalized. Finally, the structures of our corporations and major institutions reward the most ideal of ideal workers with promotions to positions of power; decision-makers are those who demonstrate ideal worker performance and expect it of others (Blair-Loy 2004).

Although these researchers believe the ideal worker norm should be abandoned or at least attenuated, there is less agreement regarding the norm as an explanation for the increase in long work hours in recent decades. All of the relevant works mention the entry of women into higher education and professional positions, and the inconsistency between parenting commitments and ideal worker performance, as a reason why long hours among ideal workers have been spotlighted in recent decades. Declining male wages (Moen and Roehling 2004: 18), long hours as a device for proving commitment and hence generating job (or at least career) security in an increasingly competitive global economy (Moen and Roehling 2004: 18; Bailyn 1993: x), and recent corporate attempts to provide and invite employee involvement and related high levels of commitment (Bailyn 1993: x; Hochschild 1997), are also mentioned as relevant factors. Although these explanations are somewhat ambiguous, most of the researchers would probably agree with Blair-Loy's claim that the ideal worker norm (or what she labels the 'work devotion schema') has become "semi-autonomous from purely economic considerations" (2004: 21) in recent decades, hence justifying the use of the term 'norm' here.

Regardless of the precise timing or rationale for the expanded reach of the ideal worker norm, the literature hypothesizes that the norm and related long work hours will be concentrated among professionals and managers, among individuals with high education levels, and will be in large measure voluntary. Most importantly, long hours should be a persistent feature of work for these individuals.

Alternative explanations, however, might also be consistent with this same pattern. Landers, Rebitzer and Taylor (1996), for example, documented the existence of long hours among lawyers. Their explanation, however, diverges from norms in that they attribute long hours to economic incentives confronting managers and professionals, and specifically a rat race where the food at the end of the maze is a promotion. Further, their model casts 
promotion incentives as selecting for promotion those individuals with a taste for long hours. This model therefore hypothesizes that long hours will be correlated with both future and past promotions.

Human capital. A different view of the role of education in explaining long hours is related to human capital theory. Here individuals who acquire human capital through formal education should receive higher hourly wages in return. To the extent that substitution (rather than income) effects are dominant, individuals with high levels of educational attainment will work long hours to effectively increase the return on their human capital investment. For the present analysis, this argument implies that caution is warranted in interpreting any correlation between education and hours as reflective of the ideal worker norm.

Cost-of-job-loss. Bowles (1985) developed a model wherein employers generate high levels of work effort by providing high wages and supervision in tandem with threats of dismissal. Schor (1991) extended this logic to argue that long hours are in part related to a high cost-of-job-loss. This approach hypothesizes that employees working the longest hours will be those with the most to lose - those who could not otherwise obtain a similar job easily.

In addition to the major theories just described, the working time literature suggests other aspects of long hours may be relevant.

Flexibility. Golden (2001) reported evidence from the May 1997 Current Population Survey of a 'u-shaped' pattern around work hours and employee access to flexible work schedules. That is, the proportions of employees with flexible schedules (defined as having the ability to vary the time work begins and ends) were highest among part-time workers and those reporting usual weekly working hours of 50 or more. For Golden these findings implied a tradeoff between leisure time and flexible work schedules. The discussions above suggest at least two reasons why flexibility would be positively related to long hours. First, to the extent the ideal worker norm is internalized, supervisors would have no reason to restrict the schedule flexibility of individuals who are presumed to adhere to the norm; ideal workers will perform at high levels regardless of policies providing time away from the workplace. Second, if schedule flexibility is seen as a benefit, then the availability of flexibility may serve to increase the cost-of-job-loss by increasing the incentive to work long hours.

Gender and family. Previous studies suggest that long hours will be related to issues of gender and parenting. Regarding gender, research continues to find women performing 
more housework than men, regardless of the presence of other family members (Bianchi et al. 2000; Lee and Waite 2005). Men are therefore more readily available for long hours of employment. Further, echoing Hochschild (1997), Barnett (1998) suggested that some men use long hours of work as a mechanism for avoiding housework. By either line of reasoning, we expect men to exhibit long work hours more frequently than women, and for any difference to be more pronounced where men and women are partnered within a household.

Regarding parenting, despite a recent increase in the time American fathers devote to child care, it remains the case that mothers continue to contribute more such time (Sandberg and Hofferth 2001). Given that income needs typically rise in the presence of children, we might therefore expect new fathers to increase and new mothers to reduce their working time, as Hamermesh (1996) found in U.S. and German data.

Complicating this pattern is the likelihood that the time and money expenditures associated with children change as they grow. Previous studies have found that parents devote more time to pre-school aged children (Nock and Kingston 1988), while expenditures rise as children enter the teen years (Schor 1999). Long work hours may, therefore, be positively correlated with the presence of school-aged children as families strive to meet expanded income demands.

Labor-leisure trade-off. In traditional economic models, work hours and the hourly wage are determined simultaneously. If substitution effects dominate, then wages and hours will be positively correlated, whereas if income effects dominate, a negative correlation will appear. Generally substitution effects are expected to dominate at lower wages levels, but as wages and incomes rise, the income effect is thought to become more pronounced, such that labor supply curves can even bend backwards. Although we do not model the wage explicitly here, we can account for the phenomenon by including variables relevant to wage determination, thereby generating a reduced form model of work hours determination. Relevant variables include education (already discussed), gender, age (specified as a quadratic), and occupation and industry dummy variables. ${ }^{2}$

The Australian context. The theories and studies cited to this point were almost exclusively developed in and for the U.S. Are they relevant to Australia? Historically, the two nations were quite different in that Australian wage determination and conditions of employment were largely centralized through a system of arbitrated industry and national awards, and trade union membership was much more extensive (Davis and Lansbury 1998). 
Since the late 1980s, however, industrial relations structures in Australia have undergone a marked transformation. Arbitrated awards have gradually been replaced by negotiated enterprise and workplace agreements as the principal mechanism for the determination of wages and conditions (Wooden 2000). Accompanying this, the rate of trade union membership has collapsed from close to half the employee workforce at the start of the 1980s to less than 23 per cent in the latest figures (for August 2004). Australia has thus clearly moved much closer to the U.S. employment relations model (Berg et al. 2004) and hence we do not expect institutional differences to be of large importance for this analysis.

As in the U.S., we expect union membership in Australia to be negatively related to long hours. ${ }^{3}$ However, one aspect of employment relations that remains unique to Australia is the distinction between casual and permanent employees. Casual employees have less job security, and typically do not receive paid holiday or sickness benefits. In lieu of such benefits, casuals often receive an hourly wage loading of 20 percent of an equivalent permanent employee's wage (Campbell 1996: 579). This loading, in addition to a tendency by employers to treat casual employees as sub-standard or marginal (Berg et al 2004), suggests a negative association between long hours and casual employment.

\section{Data}

The HILDA Survey. The data used in this analysis come from the Household, Income and Labour Dynamics in Australia (HILDA) Survey, a nation-wide household panel survey with a focus on issues relating to employment, income and the family. Described in more detail in Watson and Wooden (2004), it began in 2001 with a large national probability sample of Australian households occupying private dwellings. All members of those responding households in wave 1 form the basis of the panel to be pursued in each subsequent wave, with each wave of interviewing being approximately one year apart. After adjusting for out-of-scope dwellings (e.g., unoccupied, non-residential) and households (e.g., all occupants were overseas visitors) and for multiple households within dwellings, the total number of households identified as in-scope in wave 1 was 11,693. Interviews were completed with all eligible members at 6872 of these households and with at least one eligible member at a further 810 households. The total household response rate was, therefore, 66 per cent. Within the 7682 households at which interviews were conducted, there were 19,917 people, 4790 of whom were under 15 years of age on the preceding 30 June and hence ineligible for interview. This left 15,127 persons of whom 13,969 were successfully 
interviewed. Of this group, 11,993 were re-interviewed in wave 2 and 11,190 were reinterviewed in wave $3 .^{4}$

We initially restricted our attention to the sub-sample of persons employed in wave 1 , which provides an initial sample of 8525 observations. We lose 1892 of these observations as a result of sample attrition in waves 2 or 3. A further 343 observations are lost as a result of missing information on relevant variables. In total, we were left with 6290 observations for the analysis.

Hours variables. The working hours variables used in this analysis are derived from self-reported data on the number of hours usually worked per week in all jobs. ${ }^{5}$ To analyze long hours, we established two cut-off points: one at 50 hours per week and the other at 60 hours per week. We use these cut-offs because respondents tended to anchor on these specific figures, thereby providing natural cut-offs in the data.

Tables 1 and 2 provide information from the balanced panel of respondents on the percentage of employees working at least 50 and at least 60 hours per week, respectively. Starting with Table 1, we can see that long work weeks are very common in Australia, with almost 23 percent of employed persons reporting usual weekly working hours of 50 or more. ${ }^{6}$ We can also see that long hours working is highly persistent. Of the initial group of long hours workers, just over 70 percent were still regularly working 50 or more hours per week one year later (i.e., in wave 2), and over three-quarters of that group were working long hours two years later (i.e., in wave 3). Multiplying the last two figures, we find, for individuals reporting long hours in wave 1 , that there is a 54.6 percent chance of working long hours in all three survey waves. Although there is no absolute standard for gauging persistence, it seems reasonable to argue that the probability of long hours continuing beyond a single year is sufficiently high to warrant use of the term.

Table 2 provides comparable figures for respondents reporting at least 60 hours per week. Around 10 percent of respondents reported such hours in wave 1, over half of whom reported similarly long hours in wave 2. The net effect is that just over 42 percent of respondents claiming long hours in wave 1 reported long hours in all three waves. Again, these figures support the argument that long hours are often persistent. 
Table 1. Continuation of Long Hours (50 hours or more per week)

\begin{tabular}{|c|c|c|c|c|c|}
\hline \multicolumn{2}{|c|}{ Wave 1 (2000-01) } & \multicolumn{2}{|c|}{ Wave 2 (2001-02) } & \multicolumn{2}{|c|}{ Wave 3 (2002-03) } \\
\hline \multirow{4}{*}{ Long hours } & \multirow{4}{*}{$22.7 \%$} & \multirow{2}{*}{ Long hours } & \multirow{2}{*}{$70.6 \%$} & Long hours & $77.3 \%$ \\
\hline & & & & Not long hours & $22.7 \%$ \\
\hline & & \multirow{2}{*}{ Not long hours } & \multirow{2}{*}{$29.54 \%$} & Long hours & $29.8 \%$ \\
\hline & & & & Not long hours & $70.2 \%$ \\
\hline \multirow{4}{*}{ Not long hours } & \multirow{4}{*}{$77.3 \%$} & \multirow{2}{*}{ Long hours } & \multirow{2}{*}{$8.9 \%$} & Long hours & $52.3 \%$ \\
\hline & & & & Not long hours & $47.7 \%$ \\
\hline & & \multirow{2}{*}{ Not long hours } & \multirow{2}{*}{$91.1 \%$} & Long hours & $6.1 \%$ \\
\hline & & & & Not long hours & $93.9 \%$ \\
\hline
\end{tabular}

Note: Figures derived from a balanced sample of all persons employed in wave $1(\mathrm{~N}=6290)$, and have been weighted using longitudinal population weights.

Table 2. Continuation of Long Hours (60 hours or more per week)

\begin{tabular}{|c|c|c|c|c|c|}
\hline \multicolumn{2}{|c|}{ Wave 1 (2000-01) } & \multicolumn{2}{|c|}{ Wave 2 (2001-02) } & \multicolumn{2}{|c|}{ Wave 3 (2002-03) } \\
\hline \multirow{4}{*}{ Long hours } & \multirow{4}{*}{$9.9 \%$} & \multirow{2}{*}{ Long hours } & \multirow{2}{*}{$59.6 \%$} & Long hours & $71.2 \%$ \\
\hline & & & & Not long hours & $28.8 \%$ \\
\hline & & \multirow{2}{*}{ Not long hours } & \multirow{2}{*}{$40.4 \%$} & Long hours & $21.8 \%$ \\
\hline & & & & Not long hours & $78.2 \%$ \\
\hline \multirow{4}{*}{ Not long hours } & \multirow{4}{*}{$90.1 \%$} & \multirow{2}{*}{ Long hours } & \multirow{2}{*}{$4.6 \%$} & Long hours & $35.6 \%$ \\
\hline & & & & Not long hours & $64.4 \%$ \\
\hline & & \multirow{2}{*}{ Not long hours } & \multirow{2}{*}{$95.4 \%$} & Long hours & $3.4 \%$ \\
\hline & & & & Not long hours & $96.6 \%$ \\
\hline
\end{tabular}

Note: Figures derived from a balanced sample of all persons employed in wave $1(\mathrm{~N}=6290)$, and have been weighted using longitudinal population weights. 
A different way of viewing these data is to consider persistence as a rank-order phenomenon. Table 3 reports the distribution of long work hours by the number of waves (or years) observed working long hours. Beginning with the figures using 50 as the cut-off, around twothirds of respondents never worked long hours, just over 12 percent worked long hours in just one survey wave, around nine percent reported long hours in just two survey waves, and approximately 12 percent reported long hours in all three waves. The incidence of long hours working in each specific year of survey administration is provided at the bottom of the table. Comparing these figures to those for working long hours in all three waves reveals that a little over half (between 54 and 56 per cent) of all individuals reporting long hours at each of the three points in time persistently report the phenomenon. Using the 60 hour cut-off results in smaller estimates of long hours workers, but we again see that of those reporting long hours in each cross-section, relatively large proportions (between 42 and 45 percent) do so persistently.

Table 3. Long Hours Working - Persistence vs Incidence

\begin{tabular}{lcc}
\hline & \multicolumn{2}{c}{ Long hours cut-off } \\
\cline { 2 - 3 } & 50 hours & 60 hours \\
\hline Long hours persistence, 2001 to 2003 & & \\
(\% distribution) & & \\
$\quad$ Never worked 'long hours' & 66.2 & 83.1 \\
Worked 'long hours' in one year & 12.2 & 8.7 \\
Worked 'long hours' in two years & 9.2 & 4.0 \\
Worked 'long hours' in all three years & 12.4 & 4.2 \\
& & \\
Cross-sectional incidence of long hours (\%) & & 9.9 \\
Wave 1 (2001) & 22.7 & 10.0 \\
Wave 2 (2002) & 22.9 & 9.4 \\
Wave 3 (2003) & 22.3 & \\
\hline
\end{tabular}

Note: Figures derived from a balanced sample of all persons employed in wave $1(\mathrm{~N}=6290)$, and have been weighted using longitudinal population weights.

Independent variables. The potential correlates of long hours are described in Table 4. We discuss these variables as if they apply to long hours only, implicitly assuming that persistently long hours will follow a similar pattern. Flowing from our theoretical discussion, the initial variables address consumerism. The effects of debt are captured by the ratio of total 
Table 4. Independent Variables

\begin{tabular}{|c|c|c|c|}
\hline Variable name & Description & Mean & $\begin{array}{l}\text { Std. } \\
\text { dev. }\end{array}$ \\
\hline \multicolumn{4}{|l|}{ Theoretical variables } \\
\hline Debt/income ratio & $\begin{array}{l}\text { Ratio of household debt to annual household disposable income } \\
\text { (Wave 2) }\end{array}$ & 2.666 & 9.298 \\
\hline Debt/income-squared & Debt/income ratio squared & 93.54 & 884.13 \\
\hline No debt & Zero household debt reported (wave 2) & 0.168 & 0.374 \\
\hline \multirow[t]{2}{*}{ Diploma } & Highest educational qualification is Advanced Diploma or & & \\
\hline & Diploma & 0.093 & 0.290 \\
\hline \multirow{2}{*}{$\begin{array}{l}\text { Certificate } \\
\text { Year } 12 \text { school }\end{array}$} & Highest educational qualification is Trade or other certificate & 0.293 & 0.455 \\
\hline & $\begin{array}{l}\text { Highest educational attainment is completion of Year } 12 \text { (final } \\
\text { year of secondary school) }\end{array}$ & 0.127 & 0.333 \\
\hline Less than Year 12 & Highest educational attainment is completion of Year 11 or less & 0.242 & 0.428 \\
\hline Manager & Working in managerial occupation & 0.101 & 0.301 \\
\hline Professional & Working in professional occupation & 0.229 & 0.420 \\
\hline Promotion & Whether report promotion on the job (waves 2 and 3 ) & 0.129 & 0.336 \\
\hline Cost of job loss & $\begin{array}{l}\text { Self-reported \% chance that, in the event of job loss, the next job } \\
\text { found would be at least as good as the current job (divided by } 100 \text { ) }\end{array}$ & 0.499 & 0.405 \\
\hline Flexibility & Whether able to use flexible start and finish times if needed & 0.603 & 0.489 \\
\hline Male & Male & 0.529 & 0.499 \\
\hline Married man & Married (legal or de facto) male & 0.378 & 0.485 \\
\hline Married woman & Married (legal or de facto) woman & 0.314 & 0.464 \\
\hline Mother young child & Mother of child aged $0-4$ & 0.060 & 0.237 \\
\hline Mother older child & Mother of child aged 5-15 & 0.139 & 0.347 \\
\hline Father young child & Father of child aged 0-4 & 0.093 & 0.290 \\
\hline Father older child & Father of child aged 5-15 & 0.137 & 0.344 \\
\hline \multicolumn{4}{|l|}{ Control variables } \\
\hline Age & Years of age & 39.30 & 12.53 \\
\hline Age-sq & Years of age squared & 1701.52 & 1023.29 \\
\hline Union member & Member of trade union or employee association & 0.282 & 0.450 \\
\hline Casual & Employed on a casual basis & 0.187 & 0.390 \\
\hline Family income & $\begin{array}{l}\text { Annual household income (\$), excluding respondent’s wage and } \\
\text { salary }\end{array}$ & 37324.9 & 42878.1 \\
\hline Men x Family income & Family income interacted with male & 16087.1 & 29375.9 \\
\hline Moonlighting & Holds more than one paid job & 0.091 & 0.288 \\
\hline Buying home & Living in and paying a mortgage on a house & 0.431 & 0.495 \\
\hline Renting & Live in rental housing & 0.221 & 0.415 \\
\hline Free-board & Living with others and not paying rent & 0.018 & 0.134 \\
\hline Aboriginal & Aboriginal or Torres Straight Islander background & 0.012 & 0.108 \\
\hline ImmESB & Born overseas in one of the main English-speaking countries & 0.103 & 0.305 \\
\hline ImmNESB & $\begin{array}{l}\text { Born overseas but not in one of the main English-speaking } \\
\text { countries }\end{array}$ & 0.104 & 0.305 \\
\hline AboriginalM & Male Aboriginal & 0.005 & 0.071 \\
\hline ImmESBM & Male ImmESB & 0.061 & 0.239 \\
\hline ImmNESBM & Male ImmNESB & 0.053 & 0.224 \\
\hline Inner-regional & Resides in inner regional Australia & 0.293 & 0.455 \\
\hline Outer-regional & Resides in outer regional Australia & 0.109 & 0.311 \\
\hline Remote & Resides in remote part of Australia & 0.020 & 0.138 \\
\hline Self-employed & Owner-manager of a business (including incorporated businesses) & 0.207 & 0.405 \\
\hline Public sector & Employed by government organisation & 0.241 & 0.428 \\
\hline Job change & Changed employers in Wave 2 or 3 & 0.227 & 0.419 \\
\hline Not employed W2-W3 & Not employed in either or both Wave 2 or 3 & 0.130 & 0.336 \\
\hline
\end{tabular}

Notes: Figures derived from an unweighted analysis of HILDA Wave 1 data for all respondents employed that period and reporting in later periods ( $\mathrm{N}=6290)$. Unless stated otherwise, all variables derived from wave 1 data. 
household debt to annual disposable household income, and should be positively related to hours. A quadratic term is included to capture potential nonlinearity in the relationship with long hours (and should be negative if significant). Also due to concerns regarding nonlinearities, and given a sizable fraction of the sample (over 16 percent) reported no household debt, a dummy variable was included for that group; the variable should be negatively related to long hours. Note that these variables are drawn from wave 2 data (the only wave to date in which detailed information about household debt has been collected), so we assume the variables are relatively constant over time. Income is bottom-coded at $\$ 1$ per year, and the ratio is top-coded at 100 to reduce the effects of extreme values. ${ }^{7}$ To account for the fact that much household debt is related to housing mortgages, we add controls for whether the family is buying a home (hence paying a mortgage), renting housing, or receiving free-board, with the omitted category covering respondents owning their own homes outright (see control variables). Although we expect respondents with mortgages to work long hours, the debt variables arguably provide a stronger test of the consumerism hypothesis, particularly after controlling for mortgage payments.

For the ideal worker hypothesis, we include four educational attainment dummies, with the excluded group being respondents with a university degree. These dummies should be negatively correlated with long hours. In addition, managers and professional employees are expected to be more often subject to the ideal worker norm, so these occupation dummies should be positively related to long hours. Finally, although we cannot directly link current hours to promotion probabilities, we do have information from wave 2 and wave 3 data on whether the individual actually received a promotion since the previous wave of survey administration. Inclusion of a variable identifying promotion prior to either wave 2 or wave 3 allows us to ask whether future promotions are associated with current long hours in the cross-sectional analysis, as the rat-race model suggests, and whether promotion is related to persistence, as the ideal worker norm suggests. To pin down ideal worker effects, we control for moonlighting (i.e., holding more than one job), since the relevant literature casts ideal workers as working long hours for a single employer (Williams 1999; Blair-Loy 2004).

A cost-of-job-loss variable is derived from a question to employees about the expected probability (ranging from 0 to 100) of finding another job with similar wages and benefits if needed. The question is identical to one included in the U.S. Survey of Economic Expectations and was used by Manski and Straub (2000) to construct measures of job insecurity. Although the variable does not include either the likely duration of unemployment 
following job loss, nor expected monetary losses if a similar job were not found, it seems very relevant, and should be negatively related to hours (i.e., the effect should be reversed from that for a direct measure of the cost-of-job-loss).

A flexibility variable captures whether respondents believe they could alter their starting and finishing times flexibly if needed. Whether the variable proxies the ideal worker norm or instead the cost-of-job-loss, it should be positively related to long hours.

For gender and family, seven dummy variables are deployed. The first three dummy variables are for males, the overlapping category of married men, and for married women, where cohabitation is counted as marriage. For children we include separate dummy variables for mother of a young child (aged zero to four) and mother of an older child (aged five to 15), and similarly use variables for the father of a young child and the father of an older child. From our earlier discussion, we expect males, married men, and fathers of older children to work long hours, while married women and particularly mothers of young children are not expected to report long hours.

To account for the labor-leisure trade-off, note that the education variables may also be interpreted as operating through wage effects, as might the gender variable. In addition, an age quadratic is included, as are additional occupation and industry dummy variables (discussed below).

For the industrial relations context, dummy variables for union membership and for casual employment are included. Both should be negatively related to long hours.

Control variables included, but not mentioned thus far, include family income, for all non-respondent family income in the previous year, and men's family income the same variable interacted with the male respondent dummy). These variables should pick up pure income effects and be negatively related to hours (the labor supply literature suggests women will be more sensitive to income effects, as in Killingsworth 1993). Variables for Aboriginal Australians, immigrants with English-speaking backgrounds, immigrants with non-Englishspeaking backgrounds, and interactions of each with the male dummy are included to capture relevant cultural and gender effects. Respondents were also divided into four geographic areas, so three dummies for respondents living outside of the major cities are included to capture any geographic effects (urban residence accounts for 58 percent of the sample).Variables for the self-employed and for public sector employment are also included, since the self-employed may hold greater control over their working hours arrangements, but 
may also need long hours to maintain income security, ${ }^{8}$ while public sector employees may be less prone to long hours either because public sector unions are stronger or because jobs are sufficiently secure that employees do not feel driven to work long hours (the flip side of the cost-of-job-loss hypothesis).

Nine occupation categories were used in the analyses corresponding to the nine major occupation groups in the Australian Standard Classification of Occupations. This list includes the manager and professionals categories discussed above. The omitted category is laborers and related workers. As a test for the robustness of the results, and to shed potential light on specific occupations associated with the ideal worker norm, in an additional specification we replaced the nine major occupation groups with 35 dummy variables distinguishing 36 occupation sub-groups (with the omitted category being “intermediate clerical workers", the largest sub-group). In addition, 17 industry dummy groups were used in the analysis, corresponding to the industry divisions in the Australian and New Zealand Standard Industrial Classification. The omitted industry category is retail trade.

Finally, at the bottom of the table are control variables for the persistence analysis, constructed from wave 2 and wave 3 data. These dummy variables proxy whether the individual changed employers subsequent to wave 1 , and whether the individual was not employed at the time of either or both wave 2 or wave 3 survey administration.

\section{Methods}

The main objectives of the analyses to follow are to identify both the cross-sectional correlates of long working hours and the correlates of persistence in long hours over three waves of the HILDA Survey data. As noted earlier, to ensure comparability across the crosssectional and persistence analyses, we restrict the sample to a balanced panel of individuals employed in Wave 1 and responding in the other two waves of survey administration. ${ }^{9}$

Since the dependent variable for the cross-section analysis takes the value unity if the individual reports usual weekly hours on all jobs of at least 50 hours per week, or of at least 60 hours per week, a binary probit model is used to analyze the correlates of long hours.

To analyze persistence, we use a count variable for the number of survey waves during which respondents reported usual hours of at least either 50 or at least 60 per week. An ordered probit model is appropriate since it does not impose linearity on the distinctions between each contiguous category but does assume some underlying continuity. ${ }^{10}$ 
Note that job characteristics data from wave 1 (such as the cost-of-job-loss and flexibility) are used in the persistence analysis. Those characteristics are likely to be altered among individuals who change employers, and are misspecified for individuals who become unemployed. If we assume such effects are linear, then the inclusion of the dummy variables for job change and for not employed in the persistence analysis should correct the errors. However, as a check on any related effects, we re-ran all analyses using a balanced panel of respondents who remained with the same employer over the entire period.

\section{Results}

Cross-sectional regression estimates of the factors associated with long hours are provided in Table 5. Looking across the regressions using the 50 hour and 60 hour cut-offs, the coefficients for the debt/income ratio and its quadratic, and for holding no debt, each operate as predicted, although the coefficient for no debt never achieves significance. The maximum value for the quadratic is around 64 for the 50 hour cut-off and approximately 60 for the 60 hour cut-off. Given that 99 percent of respondents report debt to income ratios below 50, these results suggest that for the vast majority of the relevant range, higher debt to income ratios are associated with a higher probability of working long hours, albeit with a declining marginal effect as the ratio rises.

All four education coefficients are negative and significant under the 50 hour cut-off, as predicted by both the ideal worker norm and human capital considerations, but significance disappears when the 60 hour cut-off is applied. Given the missing category is for individuals with at least a bachelor's degree, we examined the mean values of that variable for various hours categories and found that, among respondents working less than 50 hours, 23.1 percent held a degree. For respondents reporting 50 to 59 hours, 35.2 percent held a degree, while for respondents at 60 hours or more, only 22.5 percent held degrees. These differences suggest that there are limits to the long hours motivated by either the ideal worker norm or high levels of human capital. Alternatively, given a correlation between educational attainment and hourly wages, the results are consistent with a backward-bending labor supply curve, such that hours rise in tandem with wages, with income effects eventually turning the relationship negative. 
Table 5. Cross-sectional Probit Estimates, Long Working Hours

\begin{tabular}{|c|c|c|c|c|}
\hline \multirow[b]{2}{*}{ Independent variable } & \multicolumn{2}{|c|}{ At least 50 hours } & \multicolumn{2}{|c|}{ At least 60 hours } \\
\hline & Coeff. & S.E. & Coeff. & S.E. \\
\hline Debt/income ratio & $.020 *$ & .008 & $.033 * *$ & .009 \\
\hline Debt/income-squared (x 100) & $-.016 *$ & .008 & $-.027 * *$ & .009 \\
\hline No debt & -.114 & .064 & -.042 & .078 \\
\hline Diploma & $-.157 *$ & .077 & -.007 & .099 \\
\hline Certificate & $-.261 * *$ & .065 & -.049 & .082 \\
\hline Year 12 school & $-.287 * *$ & .082 & -.126 & .108 \\
\hline Less than Year 12 & $-.304 * *$ & .073 & -.037 & .091 \\
\hline Manager & $.891^{* *}$ & .105 & $.578 * *$ & .128 \\
\hline Professional & $.411^{* *}$ & .106 & .179 & .135 \\
\hline Promotion & .081 & .060 & .093 & .078 \\
\hline Cost-of-job-loss & $.183^{* *}$ & .070 & $.310^{* *}$ & .094 \\
\hline Flexibility & .027 & .049 & $.203^{* *}$ & .066 \\
\hline Male & $.459 * *$ & .090 & $.380^{* *}$ & .119 \\
\hline Married man & .103 & .067 & -.011 & .084 \\
\hline Married woman & -.096 & .084 & -.087 & .119 \\
\hline Mother young child & $-.633 * *$ & .144 & $-.437 *$ & .212 \\
\hline Mother older child & $-.329 * *$ & .085 & $-.428 * *$ & .125 \\
\hline Father young child & -.055 & .069 & .101 & .081 \\
\hline Father older child & .043 & .060 & .058 & .071 \\
\hline Age & $.080 * *$ & .011 & $.080 * *$ & .014 \\
\hline Age-sq (x 100) & $-.091 * *$ & .013 & $-.083^{* *}$ & .016 \\
\hline Union member & .040 & .049 & .002 & .063 \\
\hline Casual & $-.582 * *$ & .080 & $-.421 * *$ & .108 \\
\hline Family income (x 1000) & -.0005 & .0008 & -.002 & .001 \\
\hline Men x Family income (x 1000) & .001 & .001 & $.004 * *$ & .002 \\
\hline Moonlighting & $.429 * *$ & .068 & $.563^{* *}$ & .078 \\
\hline Buying home & $.106 *$ & .053 & .065 & .065 \\
\hline Renting & $.122 *$ & .064 & .091 & .082 \\
\hline Free-board & $.325 *$ & .148 & $.421 * *$ & .160 \\
\hline Aboriginal & .026 & .317 & -.104 & .482 \\
\hline ImmESB & -.255 & .135 & -.131 & .192 \\
\hline ImmNESB & .001 & .114 & .051 & .159 \\
\hline AboriginalM & $-1.115 *$ & .518 & -.636 & 699 \\
\hline ImmESBM & .147 & .154 & .008 & .212 \\
\hline ImmNESBM & $-.347 *$ & .141 & -.231 & .189 \\
\hline Inner-regional & .036 & .049 & $.137 *$ & .062 \\
\hline Outer-regional & $.189 * *$ & .070 & $.290 * *$ & .083 \\
\hline Remote & $.335 *$ & .135 & .302 & .156 \\
\hline Self-employed & $.525^{* *}$ & .074 & $.659 * *$ & .094 \\
\hline Public sector & $-.357 * *$ & .074 & $-.226 *$ & .097 \\
\hline Chi-squared & & & & \\
\hline Cragg-Uhler pseudo R-squared & & & & \\
\hline $\mathrm{N}$ & & & & \\
\hline
\end{tabular}

Notes: Sample consists of all persons employed in Wave 1 and reporting in later periods. Regressions included a constant and an additional six occupation and 16 industry dummy variables.

* Statistically significant at the .05 level; ** at the .01 level. 
Both the professional and managerial dummies are positive and significant under the 50 hour cut-off, as predicted by the ideal worker norm arguments, though the professional coefficient loses significance with the 60 hour cut-off. The promotion coefficient is only signed as predicted.

The cost-of-job-loss coefficient is reversed in sign from that predicted and is significant, suggesting that individuals who work long hours often find it relatively easy to find alternative employment with similar wages and benefits. These individuals may be, at least in the sense of the cost-of-job-loss literature, performing long hours voluntarily. The flexibility coefficient is positive as expected, but only significant when the 60 hours cut-off is used. The signs on all seven of the gender and family coefficients are as expected, except the signs flip across the cut-offs for married men and for the fathers of young children. Regardless, only the coefficients for men (positive), and for mothers of younger and older children (negative) are significant. The age quadratic is significant, suggesting that long hours rise with age until a turning point occurs at between around 44 and 48 years of age. Given hourly wages may continue to rise beyond those ages, this result is also consistent with a backward-bending labor supply curve. The union membership effect is surprisingly positive though insignificant, while the casual coefficient is negative and significant as expected.

Most of the remaining control variables function reasonably well. Although mainly insignificant, the signs and sizes of the family income and men's family income coefficients fit the notion of income effects being related to women reducing their labor supply as family income rises, but without similar behavior among men. The moonlighting coefficient is positive and significant, suggesting it is an important control for variables proxying the ideal worker norm. Buying a home is positively and significantly correlated with long hours under the 50 hour cut-off, but not for 60 , and the free-board coefficient is consistently positive and significant, suggesting that many relevant individuals are working long hours to save for their own abode. The cultural variables suggest that Aboriginal men and male immigrants with non-English-speaking backgrounds may be less likely to work long hours. The regional coefficients suggest the prevalence of long working hours increases as we move away from the major cities towards increasingly remote areas, a finding that may be related to the types of employment available in the outback and farming areas, or perhaps because commuting time (excluded from our estimates of working time) is higher in urban areas, thereby limiting the time available for work per se. The self-employed are significantly more prone to reporting long hours, while public sector employees are less so, as expected. 
The fit of the probit regressions is reasonable, with a Cragg-Uhler pseudo-R-squared of around 0.33 for the 50 hour cut-off, and a figure slightly below that for the 60 hour cut-off.

Turning to the ordered probit results for persistence in Table 6, and again considering coefficients across the regressions using the 50 and 60 hour cut-offs, results for the consumerism hypothesis are, if anything, stronger. The debt/income ratio coefficient rises from the five to the one percent significance level, and the no debt coefficient achieves significance at the five percent level. In addition, the maximum of the age quadratic remains reasonable, with the probability of long hours rising until it hits a turning point at either age 53 or 56 , for the 50 hour and 60 hour cut-offs, respectively.

For the ideal worker and human capital variables, education again performs as predicted for the 50 hours cut-off, and again declines to insignificance when the 60 hours cutoff is applied, consistent with a backward-bending labor supply curve. In contrast to the cross-sectional findings, the coefficients for manager and professional maintain significance across the hours cut-offs, with the signs as predicted by the ideal worker norm. Also as predicted by the ideal worker norm, the promotion coefficient is positive and now significant in both equations. However, it is important to recall that this variable was constructed from items in waves 2 and 3 of the survey, suggesting that actual rather than expected promotions are relevant to persistently long hours. This finding fits the ideal worker norm explanation, but is inconsistent with the selection model of Landers, Rebitzer and Taylor (1996), since that model predicts that long hours will generate future promotions.

The cost-of-job-loss coefficient remains opposite in sign to that predicted, and retains significance as in the cross-section results. In contrast to those results, the flexibility coefficient loses significance, although the expected positive sign remains. Results for gender and family remain largely as before, as do results for age, union membership, casual employment, family income, and for moonlighting. With regard to home status, the buying home coefficient remains positive, and again loses significance when the 60 hours cut-off is applied, while renting and free-board now attract significance and a positive sign, suggesting that relevant individuals are more likely to work persistently long hours than individuals who own their own homes outright. The Aboriginal male coefficient loses significance, while the negative coefficient for immigrant men with non-English-speaking backgrounds gains in significance. The remaining coefficients and significance largely echo those from the crosssection, except that the public sector coefficient loses significance when the 60 hours cut-off 
Table 6. Persistence Ordered Probit Estimates, Long Working Hours

\begin{tabular}{|c|c|c|c|c|}
\hline \multirow[b]{2}{*}{ Independent variable } & \multicolumn{2}{|c|}{ At least 50 hours } & \multicolumn{2}{|c|}{ At least 60 hours } \\
\hline & Coeff. & S.E. & Coeff. & S.E. \\
\hline Debt/income ratio & $.024 * *$ & .007 & $.036^{* *}$ & .008 \\
\hline Debt/income-squared (x 100) & $-.023 * *$ & .007 & $-.032 * *$ & .008 \\
\hline No debt & $-.136 *$ & .054 & -.087 & .064 \\
\hline Diploma & $-.182 * *$ & .065 & -.054 & .080 \\
\hline Certificate & $-.250 * *$ & .055 & -.066 & .067 \\
\hline Year 12 school & $-.284 * *$ & .068 & -.112 & .085 \\
\hline Less than Year 12 & $-.271 * *$ & .062 & -.012 & .074 \\
\hline Manager & $.877 * *$ & .087 & $.678 * *$ & .104 \\
\hline Professional & $.396^{* *}$ & .087 & $.280 * *$ & .107 \\
\hline Promotion & $.250 * *$ & .049 & $.156^{* *}$ & .061 \\
\hline Cost-of-job-loss & $.187 * *$ & .059 & $.213^{* *}$ & .074 \\
\hline Flexibility & .004 & .041 & .064 & .052 \\
\hline Male & $.431^{* *}$ & .074 & $.331 * *$ & .092 \\
\hline Married man & $.144^{*}$ & .057 & .061 & .069 \\
\hline Married woman & -.050 & .068 & -.108 & .090 \\
\hline Mother young child & $-.600 * *$ & .111 & $-.526^{* *}$ & .160 \\
\hline Mother older child & $-.343 * *$ & .068 & $-.339 * *$ & .091 \\
\hline Father young child & -.066 & .059 & .049 & .068 \\
\hline Father older child & .061 & .052 & -.003 & .059 \\
\hline Age & $.069 * *$ & .010 & $.078 * *$ & .012 \\
\hline Age-sq (x 100) & $-.082 * *$ & .011 & $-.086 * *$ & .014 \\
\hline Union member & .007 & .042 & -.016 & .051 \\
\hline Casual & $-.455 * *$ & .062 & $-.388 * *$ & .082 \\
\hline Family income (x 1000) & -.001 & .0007 & -.001 & .0009 \\
\hline Men x Family income (x 1000) & .001 & .0009 & $.002 *$ & .001 \\
\hline Moonlighting & $.337 * *$ & .057 & $.419 * *$ & .065 \\
\hline Buying home & $.092^{*}$ & .044 & .039 & .053 \\
\hline Renting & $.135 *$ & .053 & $.178^{* *}$ & .064 \\
\hline Free-board & $.337 * *$ & .127 & $.467 * *$ & .135 \\
\hline Aboriginal & -.091 & .269 & .105 & .313 \\
\hline ImmESB & -.135 & .105 & -.168 & .145 \\
\hline ImmNESB & .136 & .089 & -.028 & .128 \\
\hline AboriginalM & -.561 & .377 & -.634 & .468 \\
\hline ImmESBM & .120 & .123 & .014 & .164 \\
\hline ImmNESBM & $-.400 * *$ & .114 & -.087 & .152 \\
\hline Inner-regional & .050 & .041 & $.183^{* *}$ & .050 \\
\hline Outer-regional & $.202 * *$ & .059 & $.320 * *$ & .068 \\
\hline Remote & $.265^{*}$ & .119 & $.304^{*}$ & .131 \\
\hline Self-employed & $.571 * *$ & .063 & $.738 * *$ & .076 \\
\hline Public sector & $-.245 * *$ & .062 & -.103 & .077 \\
\hline Job change & .038 & .042 & .055 & .052 \\
\hline Not employed W2-W3 & $-.603^{* *}$ & .064 & $-.491 * *$ & .082 \\
\hline Chi-squared & \multicolumn{2}{|c|}{$2116.85^{* *}$} & \multicolumn{2}{|c|}{$1403.34 * *$} \\
\hline Cragg-Uhler pseudo R-squared & \multicolumn{2}{|c|}{.330} & \multicolumn{2}{|c|}{.280} \\
\hline $\mathrm{N}$ & \multicolumn{2}{|c|}{6290} & \multicolumn{2}{|c|}{6290} \\
\hline
\end{tabular}

Notes: Sample consists of all persons employed in Wave 1 and reporting in later periods. Regressions included a constant and an additional six occupation and 16 industry dummy variables.

* Statistically significant at the .05 level; ** at the .01 level. 
is applied. Not surprisingly, respondents who were not employed in either wave 2 or wave 3 were significantly less likely to report long hours. The pseudo-R-squared statistics for the regressions are slightly smaller, but basically mirror those from the cross-sectional analysis.

As a test for the robustness of the results, the regressions reported in Tables 5 and 6 were replicated after switching in the 35 two-digit occupation dummies. ${ }^{11}$ For the variables of theoretical interest, only minor changes in the size or significance of coefficients occurred. For the cross-sectional probits, the debt/income-squared and diploma coefficients remained similar in size and sign, but lost significance at the five percent level with the 50 hour cut-off. For the persistence ordered probits, sign and significance remained identical after inclusion of the detailed occupational dummies, again suggesting the persistence results are more stable. Regarding control variables, the regional coefficients declined in significance, consistent with geographic occupational patterns therefore explaining part of the apparently lesser incidence of long hours in urban areas. ${ }^{12}$

Four managerial sub-group dummies were available, and three were significant in the cross-section (the exception being "managers not otherwise classified"), while all four were significant and positively related to long hours using either hours cut-off in the persistence analysis, suggesting the norm is pervasive across the managerial ranks. Note, however, that one of the four sub-groups was for farmers, who are arguably not subject to the ideal worker norm. ${ }^{13}$ Among professionals, neither science, building and engineering professionals, nor business and information professionals (except with the 50 hour cut-off), nor health professionals exhibited significant positive associations with persistently long hours, results that might in part be due to the mixing of diverse groups (such as doctors and nurses) even with two-digit occupational data. Instead, education professionals and social, arts and miscellaneous professionals drive the positive association between professional occupations and persistently long hours. The connection between higher education and long hours has been discussed by earlier researchers (e.g., Bailyn 1993), and the connection between long hours and elementary school teaching has been documented previously as well (Drago et al. 1999). Note also that the social, arts and miscellaneous professionals group includes lawyers, as well as broadcasters, actors, journalists and pilots, all occupations where we might expect the ideal worker norm to be operative. Long hours were also associated with several nonmanagerial and non-professional occupations, including road and rail transport drivers, suggesting long hours are not always connected to the ideal worker norm. 
Given that we applied wave 1 job characteristics data to respondents who later changed jobs or became unemployed, a final specification test involved replicating the persistence regressions for the smaller balanced panel of 4110 respondents that remained with the same employer in all three waves. In general, the results can be described as reasonably robust. For exceptions among variables of theoretical interest, the debt/income-squared coefficient lost significance with a slight rise in absolute value and the no debt coefficient lost significance at the five percent level using the 50 hour cut-off. Using the 60 hour cut-off, the promotion coefficient rose in absolute value but lost significance, the cost-of-job-loss coefficient remained positive and of virtually the same size but lost significance, while the male coefficient remained positive but with significance reduced from the one to the five percent level.

Given most differences in the sub-sample were due to alterations in significance, rather than substantial changes in the size of the coefficients, it is worth considering effect sizes. Simulations were therefore run with the persistence ordered probits. The estimated probabilities for either never working long hours and for persistently reporting long hours, for both the 50 and 60 hour cut-offs, are reported in Table 7. For the consumerism hypothesis, we vary the debt/income ratio from a value of zero to four, altering the quadratic and no debt accordingly. The debt/income value of four was selected because that is around the limit that most financial institutions in Australia set when determining the capacity to borrow (though this varies markedly with individual circumstances; Headey and Wooden 2005), and is certainly far more reasonable than values such as 50 . According to the simulation results, individuals with the higher debt/income ratio are almost twice as likely to work long hours across the entire three year period (.073 compared to .047 or .016 compared to .009). For education, comparing an individual with less than a high school diploma to one with a bachelor's degree suggests the latter individual is almost twice as likely to work over 50 hours persistently, but no more likely to work beyond 60 hours. For managers, as the large coefficients would lead us to expect, the probability of working persistently long hours is around triple that for non-managers, while professional employees are only slightly more likely to work persistently long hours. Respondents who received a promotion during the time period exhibited a probability around half as large again of working persistently long hours compared to others, and an increase in the ease of finding a similar job also raises the probability of persistently long hours by a factor of around a half. These simulations suggest that the magnitude of the effects identified here is not trivial. 
Table 7. Simulated Probabilities for the Persistence of Long Hours (50 and 60 hours cut-offs)

\begin{tabular}{lccccc}
\hline & \multicolumn{2}{c}{50 hours cut-off } & & \multicolumn{2}{c}{60 hours cut-off } \\
\cline { 2 - 3 } \cline { 5 - 6 } \multicolumn{1}{c}{ Variable (value) } & $\begin{array}{c}\text { Not long hours } \\
\text { all 3 waves }\end{array}$ & $\begin{array}{c}\text { Long hours all } \\
\text { 3 waves }\end{array}$ & & $\begin{array}{c}\text { Not long hours } \\
\text { all 3 waves }\end{array}$ & $\begin{array}{c}\text { Long hours all } \\
\text { 3 waves }\end{array}$ \\
\hline No debt (1) & 0.765 & 0.047 & & 0.915 & 0.009 \\
Debt/income ratio (4) & 0.690 & 0.073 & & 0.874 & 0.016 \\
Less than Year 12 (1) & 0.741 & 0.054 & & 0.885 & 0.014 \\
Bachelor Degree & 0.646 & 0.091 & & 0.883 & 0.014 \\
Manager (0) & 0.744 & 0.053 & & 0.903 & 0.011 \\
Manager (1) & 0.516 & 0.159 & & 0.797 & 0.034 \\
Professional (0) & 0.744 & 0.053 & & 0.902 & 0.011 \\
Professional (1) & 0.699 & 0.070 & & 0.891 & 0.013 \\
Promotion (0) & 0.726 & 0.060 & & 0.895 & 0.012 \\
Promotion (1) & 0.637 & 0.096 & & 0.863 & 0.018 \\
Cost-of-job-loss (0) & 0.745 & 0.053 & & 0.909 & 0.010 \\
Cost-of-job-loss (100) & 0.682 & 0.076 & & 0.870 & 0.017 \\
\hline
\end{tabular}

Notes: For No debt (1), Debt/Income was set to zero. For Debt/Income (4), No debt was set to zero, and Debt/income-squared to 16. For Less than year12 (1), other educational dummies were set to zero. For Bachelor Degree, all educational dummies were set to zero. For Manager (1), and for Professional (1), all other occupation dummies were set to zero.

\section{Discussion}

Although very long hours of work among some workers have been documented previously for the U.S. and Australia, the analysis here is the first to demonstrate that such hours are often reported persistently over a period of years. For a sample of Australian employees, we estimate that more than half reporting over 50 hours per week in a crosssection will also report working similarly long hours when re-interviewed one and two years later. Somewhat less persistence was found among employees reporting over 60 hours per week, where a little more than 40 percent of those claiming such long hours in a cross-section also reported those hours over the entire period.

Four explanations for long hours were tested. The consumerism hypothesis received the strongest support. The "work-and-spend” logic for long hours, wherein some individuals and families become caught in a web of consumer debt, and work long hours to sustain high levels of consumption, fits the results well. This logic is particularly supported by the stronger and more stable pattern of results associating debt with persistently long hours of work. 
The ideal worker norm suggests that professionals and managers, with high levels of education, promotion opportunities, and flexible work hours arrangements, will work persistently long hours. The signs of all relevant coefficients, across all specifications, were consistent with the hypotheses. Further, the results for the managerial and professional occupation variables, and for promotions, became stronger in the persistence analysis, consistent with the vision of the ideal worker exhibiting high levels of commitment for periods of years at a stretch. However, the additional work hours flexibility we expected ideal workers to be given was only significantly related to long hours in one cross-sectional regression (for 60 hours). Note also that we might interpret the negative relationship between casual employment and long hours as reflecting the possibility that casual employees are not subject to the ideal worker norm; indeed, they might be excluded.

The human capital explanation for long hours receives some support here. Specifically, for hours beyond 50, but below 60, higher levels of education are closely correlated with long hours. At 60 hours or beyond, however, there is no statistical relationship between education and long hours in either the cross-section or persistence analysis. A backward-bending labor supply curve is consistent with these results.

The substantial decline in the education coefficients for the 60 hour cut-off might imply that the human capital (or backward-bending labor supply) explanation for long hours is more salient than the ideal worker norm - at least in as much as the norm should be linked to education. However, a closer examination of the persistence results (Table 6) finds that each ideal worker coefficient declined in absolute value as the hour cut-off was raised from 50 to 60. Therefore, both the human capital and ideal worker norm as explanations for long hours receive some support here.

The cost-of-job-loss logic, wherein employers provide high wages and good benefits to motivate long hours of work, received no support in the analysis. Indeed, the reported ability of an employee to find alternative employment, with similar wages and benefits, was positively and significantly related to long hours under all specifications. In the cost-of-jobloss framework, this result implies that long hours of work are typically voluntary. Although other explanations could be relevant, the most compelling explanation for this finding across the theories considered here lies in the ideal worker norm. The fact that long hours are often in some sense voluntary fits cleanly with the notion that the ideal worker norm tends to be internalized; employees often exhibit high levels of commitment regardless of opportunities 
to find alternative employment with shorter hours. The negative cost-of-job-loss result can therefore be interpreted as consistent with the ideal worker norm. ${ }^{14}$

Several control variables were also significantly correlated with long hours. Multiple job holding, or moonlighting, and self-employment were positively related to long hours in all specifications. These findings fill in part of the long hours picture that the ideal worker literature misses, since ideal workers are typically cast as corporate employees dedicated to a single job with an associated career path.

It is also worth mentioning one unexpected result. Contrary to Hamermesh's (1996) finding that fathers typically work long hours, we found no significant correlation with long hours for fathers of either younger or older children. Indeed, the signs were not even consistent across the various regressions. Perhaps some men continue to ramp up hours as a breadwinner response to child-rearing but, if that is true, then there also exists a group of fathers behaving quite differently and avoiding long hours to spend more time with their children.

For individuals and policy-makers concerned with potentially adverse effects on health, family commitments or personal development from very long work hours, the analysis strikes an ominous note: long hours reported at any point in time are in fact often persistent. The results also, however, suggest mechanisms for reducing the prevalence of long hours. Most obviously, to the extent consumerism generates long hours, families could restrict their consumption expenditures, and simultaneously create more leisure and family time, while limiting the environmental damage associated with consumerism (Schor 1999).

Regarding the ideal worker norm as a source of long hours, changing the norm is likely to prove difficult. Bailyn (1993) suggests work redesign initiatives with the dual agenda of gender equity and workplace performance as a way to reign in the norm. Williams (1999) suggests that legal prohibitions regarding discrimination against caregiving could also help, while Moen and Roehling (2004) conclude that individuals, families, corporations and policy-makers need to rethink the meaning of career success to provide more space for families and changes over the life course. These prescriptions would be difficult to fill in practice, but might be worthwhile nonetheless.

Another part of the long hours story, suggested by the education, occupation, and age results, concerns a backward-bending supply of long hours. Rising wages may drive long hours up through a turning point, with further wage increases generating reduced hours due to 
dominant income effects. To the extent labor supply considerations are relevant, related long hours are voluntary, and the value of efforts to limit long work hours is questionable.

Given a substantial degree of institutional convergence in recent years, it is not surprising that theories built to understand experiences in the U.S. hold up in the Australian context. There may even be a substantial degree of universality to the dynamics given the global expansion of consumer markets and of employment among multinational corporations. Even if this argument is correct, however, institutional differences would likely alter the strength of relevant effects; indeed, the prohibition against usual weekly hours beyond 48 in the European Union suggests the analysis might be of less relevance there. Perhaps most importantly, however, the results in large measure support previous U.S. studies that took cross-sectional findings of long hours as reflective of persistently long hours. 


\section{Appendix}

Appendix Table A1. Descriptives for Occupational and Industry Dummy Variables

\begin{tabular}{lcc}
\hline & Mean & Std. dev. \\
\hline Occupation dummies & & \\
Associate professional & 0.116 & 0.321 \\
Tradespersons and related workers & 0.114 & 0.318 \\
Advanced clerical and service workers & 0.035 & 0.185 \\
Intermediate clerical, sales and service workers & 0.162 & 0.368 \\
Intermediate production and transport workers & 0.072 & 0.258 \\
Elementary clerical, sales and service workers & 0.089 & 0.284 \\
Industry dummies & & \\
Agriculture, forestry and fishing & 0.060 & 0.238 \\
Mining & 0.014 & 0.119 \\
Manufacturing & 0.104 & 0.305 \\
Electricity, gas and water supply & 0.009 & 0.094 \\
Construction & 0.065 & 0.247 \\
Wholesale trade & 0.036 & 0.185 \\
Accommodation, cafes and restaurants & 0.046 & 0.210 \\
Transport and storage & 0.039 & 0.194 \\
Communication & 0.023 & 0.148 \\
Finance and insurance & 0.034 & 0.181 \\
Property and business services & 0.109 & 0.312 \\
Government administration and defence & 0.043 & 0.204 \\
Education & 0.102 & 0.302 \\
Health and community services & 0.119 & 0.323 \\
Cultural and recreational services & 0.031 & 0.172 \\
Personal and other services & 0.039 & 0.194 \\
\hline
\end{tabular}


Appendix Table A2. Cross-sectional Probit Estimates, Long Hours (model using 2-digit Occupation dummies)

\begin{tabular}{|c|c|c|c|c|}
\hline \multirow[b]{2}{*}{ Variable } & \multicolumn{2}{|c|}{ At least 50 hours } & \multicolumn{2}{|c|}{ At least 60 hours } \\
\hline & Coeff. & S.E. & Coeff. & S.E. \\
\hline Debt/income ratio & $0.020 *$ & 0.008 & $0.033 * *$ & 0.009 \\
\hline Debt/income-squared (x 100) & -.016 & 0.008 & $-0.027 * *$ & 0.009 \\
\hline No debt & -0.113 & 0.064 & -0.034 & 0.080 \\
\hline Diploma & -0.151 & 0.077 & 0.014 & 0.100 \\
\hline Certificate & $-0.281 * *$ & 0.067 & -0.032 & 0.085 \\
\hline Year 12 school & $-0.290 * *$ & 0.083 & -0.116 & 0.111 \\
\hline Less than Year 12 & $-0.318 * *$ & 0.076 & -0.012 & 0.095 \\
\hline Promotion & 0.085 & 0.061 & 0.094 & 0.080 \\
\hline Cost-of-job-loss & $0.170^{*}$ & 0.071 & $0.306^{* *}$ & 0.096 \\
\hline Flexibility & 0.044 & 0.050 & $0.213^{* *}$ & 0.068 \\
\hline Male & $0.483^{* *}$ & 0.091 & $0.403^{* *}$ & 0.121 \\
\hline Married man & 0.095 & 0.068 & -0.021 & 0.085 \\
\hline Married woman & -0.100 & 0.085 & -0.079 & 0.122 \\
\hline Mother young child & $-0.640 * *$ & 0.147 & $-0.436 *$ & 0.216 \\
\hline Mother older child & $-0.338 * *$ & 0.086 & $-0.436 * *$ & 0.126 \\
\hline Father young child & -0.050 & 0.069 & 0.096 & 0.083 \\
\hline Father older child & 0.047 & 0.061 & 0.060 & 0.072 \\
\hline Age & $0.077 * *$ & 0.011 & $0.076^{*}$ & 0.014 \\
\hline Age-sq (x 100) & $-0.089 * *$ & 0.014 & -0.079 & 0.017 \\
\hline Union member & 0.055 & 0.051 & 0.026 & 0.065 \\
\hline Casual & $-0.566^{* *}$ & 0.082 & -0.417 & 0.111 \\
\hline Family income (x 1000) & -0.0004 & 0.0008 & -0.002 & 0.001 \\
\hline Men x Family income (x 1000) & 0.001 & 0.001 & $0.004 *$ & 0.002 \\
\hline Moonlighting & $0.438 * *$ & 0.069 & $0.575^{* *}$ & 0.079 \\
\hline Buying home & $0.107^{*}$ & 0.053 & 0.068 & 0.067 \\
\hline Renting & 0.114 & 0.065 & 0.082 & 0.083 \\
\hline Free-board & $0.311^{*}$ & 0.149 & $0.409 *$ & 0.162 \\
\hline Aboriginal & 0.080 & 0.324 & -0.100 & 0.503 \\
\hline ImmESB & $-0.269 *$ & 0.138 & -0.003 & 0.216 \\
\hline ImmNESB & 0.002 & 0.116 & 0.228 & 0.192 \\
\hline AboriginalM & $-1.254 *$ & 0.528 & -0.726 & 0.719 \\
\hline ImmESBM & 0.154 & 0.157 & -0.003 & 0.216 \\
\hline ImmNESBM & $-0.353 *$ & 0.143 & -0.228 & 0.192 \\
\hline Inner-regional & 0.004 & 0.050 & 0.101 & 0.063 \\
\hline Outer-regional & $0.171^{*}$ & 0.071 & $0.257^{* *}$ & 0.084 \\
\hline Remote & $0.293 *$ & 0.137 & 0.229 & 0.160 \\
\hline Self-employed & $0.498 * *$ & 0.077 & $0.635^{* *}$ & 0.098 \\
\hline Public sector & $-0.326 * *$ & 0.075 & $-0.218 *$ & 0.099 \\
\hline Managers and administrators (n.e.c) & 0.728 & 0.520 & 0.935 & 0.527 \\
\hline Generalist managers & $0.658 * *$ & 0.156 & $0.682^{* *}$ & 0.194 \\
\hline Specialist managers & $0.801 * *$ & 0.119 & $0.651^{* *}$ & 0.164 \\
\hline Farmers and farm managers & $0.609 * *$ & 0.185 & 0.309 & 0.218 \\
\hline Science, building, engineering professionals & 0.004 & 0.165 & 0.147 & 0.226 \\
\hline Business and information professionals & 0.135 & 0.120 & -0.137 & 0.188 \\
\hline Health professionals & 0.115 & 0.174 & 0.087 & 0.239 \\
\hline Education professionals & $0.541^{* *}$ & 0.162 & 0.341 & 0.224 \\
\hline Social, arts and misc professionals & $0.465 * *$ & 0.136 & $0.527 * *$ & 0.184 \\
\hline
\end{tabular}


Table A2 (cont'd)

\begin{tabular}{|c|c|c|c|c|}
\hline \multirow[b]{2}{*}{ Variable } & \multicolumn{2}{|c|}{ At least 50 hours } & \multicolumn{2}{|c|}{ At least 60 hours } \\
\hline & Coeff. & S.E. & Coeff. & S.E. \\
\hline Science, engineering, related assoc profs & 0.015 & 0.189 & 0.235 & 0.253 \\
\hline Business / administration assoc profs & $0.337 * *$ & 0.131 & 0.314 & 0.188 \\
\hline Managing supervisors & $0.931^{* *}$ & 0.129 & $0.939 * *$ & 0.170 \\
\hline Health and welfare associate professionals & $0.707 * *$ & 0.274 & 0.554 & 0.375 \\
\hline Other associate professionals & -0.077 & 0.229 & 0.001 & 0.333 \\
\hline Mechanical and fabrication engineering & $0.400^{*}$ & 0.160 & $0.470 *$ & 0.212 \\
\hline Automotive tradespersons & 0.130 & 0.217 & 0.077 & 0.292 \\
\hline Electrical and electronics tradespersons & 0.053 & 0.164 & 0.196 & 0.221 \\
\hline Construction tradespersons & -0.002 & 0.167 & 0.093 & 0.227 \\
\hline Food tradespersons & $0.568^{* *}$ & 0.208 & $0.847 * *$ & 0.246 \\
\hline Skilled agricultural etc tradespersons & -0.105 & 0.202 & 0.175 & 0.249 \\
\hline Other tradespersons and related workers & $0.342 *$ & 0.154 & $0.463 *$ & 0.205 \\
\hline Secretaries and personal assistants & 0.182 & 0.208 & 0.196 & 0.306 \\
\hline Other advanced clerical / service workers & -0.192 & 0.204 & 0.138 & 0.257 \\
\hline Intermediate sales and related workers & $0.488^{* *}$ & 0.165 & $0.609 * *$ & 0.215 \\
\hline Intermediate service workers & 0.190 & 0.147 & 0.229 & 0.204 \\
\hline Intermediate plant operators & 0.326 & 0.175 & 0.376 & 0.233 \\
\hline Intermediate machine operators & 0.394 & 0.215 & $0.577 *$ & 0.276 \\
\hline Road and rail transport drivers & $0.514 * *$ & 0.144 & $0.661 * *$ & 0.186 \\
\hline Other intermed production / transport wrkrs & -0.145 & 0.172 & 0.058 & 0.235 \\
\hline Elementary clerks & 0.164 & 0.270 & $0.877 * *$ & 0.316 \\
\hline Elementary sales workers & -0.006 & 0.154 & 0.088 & 0.220 \\
\hline Elementary service workers & -0.116 & 0.243 & -0.458 & 0.445 \\
\hline Cleaners & -0.372 & 0.229 & 0.046 & 0.269 \\
\hline Factory laborers & 0.040 & 0.195 & -0.594 & 0.447 \\
\hline Other laborers and related workers & -0.214 & 0.154 & 0.043 & 0.200 \\
\hline Chi-squared & \multicolumn{2}{|c|}{$1640.55^{* *}$} & \multicolumn{2}{|c|}{$1039.99 * *$} \\
\hline Cragg-Uhler pseudo R-squared & \multicolumn{2}{|c|}{.350} & \multicolumn{2}{|c|}{.319} \\
\hline $\mathrm{N}$ & \multicolumn{2}{|c|}{6290} & \multicolumn{2}{|c|}{6290} \\
\hline
\end{tabular}

Notes: Sample consists of all persons employed in Wave 1 and reporting in later periods.

* Statistically significant at the .05 level; ** at the .01 level. 
Appendix Table A3. Persistence Ordered Probit Estimates, Long Hours (model using 2-digit occupation dummies)

\begin{tabular}{|c|c|c|c|c|}
\hline \multirow[b]{2}{*}{ Variable } & \multicolumn{2}{|c|}{ At least 50 hours } & \multicolumn{2}{|c|}{ At least 60 hours } \\
\hline & Coeff. & S.E. & Coeff. & S.E. \\
\hline Debt/income ratio & $0.024 * *$ & 0.007 & $0.037 * *$ & 0.008 \\
\hline Debt/income-squared (x 100) & $-0.023 * *$ & 0.007 & $-0.032 * *$ & 0.008 \\
\hline No debt & $-0.135 *$ & 0.054 & -0.083 & 0.065 \\
\hline Diploma & $-0.177 * *$ & 0.066 & -0.045 & 0.081 \\
\hline Certificate & $-0.259 * *$ & 0.057 & -0.060 & 0.068 \\
\hline Year 12 school & $-0.272 * *$ & 0.069 & -0.099 & 0.086 \\
\hline Less than Year 12 & $-0.264 * *$ & 0.064 & 0.008 & 0.076 \\
\hline Promotion & $0.258 * *$ & 0.049 & $0.163 * *$ & 0.062 \\
\hline Cost-of-job-loss & $0.168 * *$ & 0.059 & $0.207 * *$ & 0.075 \\
\hline Flexibility & 0.026 & 0.042 & 0.082 & 0.053 \\
\hline Male & $0.462 * *$ & 0.075 & $0.367 * *$ & 0.094 \\
\hline Married man & $0.136 *$ & 0.058 & 0.050 & 0.069 \\
\hline Married woman & -0.054 & 0.069 & -0.100 & 0.091 \\
\hline Mother young child & $-0.600 * *$ & 0.113 & $-0.539 * *$ & 0.163 \\
\hline Mother older child & $-0.355 * *$ & 0.069 & $-0.342 * *$ & 0.092 \\
\hline Father young child & -0.062 & 0.059 & 0.046 & 0.068 \\
\hline Father older child & 0.060 & 0.052 & -0.003 & 0.060 \\
\hline Age & $0.067 * *$ & 0.010 & $0.075^{* *}$ & 0.012 \\
\hline Age-sq (x 100) & $-0.081 * *$ & 0.012 & $-0.084 * *$ & 0.014 \\
\hline Union member & 0.018 & 0.043 & 0.002 & 0.052 \\
\hline Casual & $-0.454 * *$ & 0.063 & $-0.383 * *$ & 0.084 \\
\hline Family income (x 1000) & -0.001 & 0.001 & -0.001 & 0.001 \\
\hline Men x Family income (x 1000) & 0.001 & 0.001 & 0.002 & 0.001 \\
\hline Moonlighting & $0.340 * *$ & 0.058 & $0.421 * *$ & 0.066 \\
\hline Buying home & $0.090 *$ & 0.045 & 0.039 & 0.054 \\
\hline Renting & $0.131^{*}$ & 0.053 & $0.172 * *$ & 0.065 \\
\hline Free-board & $0.324 *$ & 0.128 & $0.465 * *$ & 0.137 \\
\hline Aboriginal & -0.015 & 0.271 & 0.217 & 0.311 \\
\hline ImmESB & -0.144 & 0.107 & -0.181 & 0.150 \\
\hline ImmNESB & 0.149 & 0.091 & -0.009 & 0.129 \\
\hline AboriginalM & -0.738 & 0.384 & -0.851 & 0.472 \\
\hline ImmESBM & 0.122 & 0.125 & 0.021 & 0.168 \\
\hline ImmNESBM & $-0.415^{* *}$ & 0.115 & -0.099 & 0.154 \\
\hline Inner-regional & 0.021 & 0.042 & $0.153^{*}$ & 0.050 \\
\hline Outer-regional & $0.186^{* *}$ & 0.060 & $0.299 *$ & 0.069 \\
\hline Remote & 0.230 & 0.120 & 0.258 & 0.133 \\
\hline Self-employed & $0.544^{* *}$ & 0.066 & 0.719 & 0.079 \\
\hline Public sector & $-0.210 * *$ & 0.063 & -0.091 & 0.078 \\
\hline Job change & 0.032 & 0.043 & 0.054 & 0.053 \\
\hline Not employed W2-W3 & $-0.625 * *$ & 0.065 & $-0.513^{* *}$ & 0.083 \\
\hline Managers and administrators (n.e.c) & $1.144^{*}$ & 0.463 & $0.986 *$ & 0.451 \\
\hline Generalist managers & $0.774 * *$ & 0.135 & $0.665 * *$ & 0.155 \\
\hline Specialist managers & $0.927 * *$ & 0.101 & $0.739 * *$ & 0.126 \\
\hline Farmers and farm managers & $0.688 * *$ & 0.157 & $0.504^{* *}$ & 0.179 \\
\hline Science, building, engineering professionals & 0.155 & 0.140 & 0.130 & 0.177 \\
\hline Business and information professionals & $0.232 *$ & 0.101 & 0.104 & 0.134 \\
\hline Health professionals & 0.178 & 0.142 & 0.081 & 0.189 \\
\hline Education professionals & $0.910^{* *}$ & 0.138 & $0.705^{* *}$ & 0.176 \\
\hline
\end{tabular}


Table A3 (cont'd)

\begin{tabular}{|c|c|c|c|c|}
\hline \multirow[b]{2}{*}{ Variable } & \multicolumn{2}{|c|}{ At least 50 hours } & \multicolumn{2}{|c|}{ At least 60 hours } \\
\hline & Coeff. & S.E. & Coeff. & S.E. \\
\hline Social, arts and miscellaneous professionals & $0.474^{* *}$ & 0.116 & $0.410 * *$ & 0.145 \\
\hline Science, engineering, related assoc profs & 0.164 & 0.159 & 0.052 & 0.206 \\
\hline Business / administration assoc profs & $0.468 * *$ & 0.110 & $0.303^{*}$ & 0.145 \\
\hline Managing supervisors & $0.928 * *$ & 0.110 & $0.829 * *$ & 0.133 \\
\hline Health and welfare associate professionals & $0.686^{* *}$ & 0.235 & 0.494 & 0.310 \\
\hline Other associate professionals & -0.086 & 0.189 & 0.176 & 0.227 \\
\hline Mechanical and fabrication engineering & $0.474 * *$ & 0.136 & 0.325 & 0.171 \\
\hline Automotive tradespersons & 0.127 & 0.187 & 0.148 & 0.226 \\
\hline Electrical and electronics tradespersons & 0.112 & 0.138 & 0.130 & 0.176 \\
\hline Construction tradespersons & 0.128 & 0.141 & -0.023 & 0.180 \\
\hline Food tradespersons & $0.718^{* *}$ & 0.178 & $0.861 * *$ & 0.198 \\
\hline Skilled agricultural etc tradespersons & -0.054 & 0.170 & 0.005 & 0.207 \\
\hline Other tradespersons and related workers & 0.226 & 0.133 & 0.288 & 0.165 \\
\hline Secretaries and personal assistants & 0.306 & 0.166 & 0.121 & 0.238 \\
\hline Other advanced clerical / service workers & -0.206 & 0.170 & -0.037 & 0.209 \\
\hline Intermediate sales and related workers & $0.476 * *$ & 0.141 & $0.449 * *$ & 0.174 \\
\hline Intermediate service workers & $0.320^{* *}$ & 0.118 & 0.253 & 0.154 \\
\hline Intermediate plant operators & $0.314^{*}$ & 0.152 & $0.420 *$ & 0.181 \\
\hline Intermediate machine operators & 0.299 & 0.188 & $0.446 *$ & 0.225 \\
\hline Road and rail transport drivers & $0.621^{* *}$ & 0.124 & $0.678 * *$ & 0.146 \\
\hline Other intermed production / transport & 0.010 & 0.140 & 0.059 & 0.178 \\
\hline Elementary clerks & 0.217 & 0.220 & $0.625 *$ & 0.256 \\
\hline Elementary sales workers & 0.202 & 0.120 & 0.054 & 0.164 \\
\hline Elementary service workers & 0.004 & 0.192 & -0.497 & 0.327 \\
\hline Cleaners & -0.140 & 0.173 & -0.146 & 0.221 \\
\hline Factory laborers & -0.036 & 0.165 & -0.125 & 0.236 \\
\hline Other laborers and related workers & -0.029 & 0.123 & 0.056 & 0.153 \\
\hline Chi-squared & \multicolumn{2}{|c|}{$225294 * *$} & \multicolumn{2}{|c|}{$1492.23 * *$} \\
\hline Cragg-Uhler Pseudo-R-squared & \multicolumn{2}{|c|}{.348} & \multicolumn{2}{|c|}{.296} \\
\hline $\mathrm{N}$ & \multicolumn{2}{|c|}{6290} & \multicolumn{2}{|c|}{6290} \\
\hline
\end{tabular}

Notes: Sample consists of all persons employed in Wave 1 and reporting in later periods.

* Statistically significant at the .05 level; ** at the .01 level. 
Appendix Table A4. Persistence Ordered Probit Estimates, Long Hours (persons employed with same employer all 3 waves)

\begin{tabular}{|c|c|c|c|c|}
\hline \multirow[b]{2}{*}{ Variable } & \multicolumn{2}{|c|}{ At least 50 hours } & \multicolumn{2}{|c|}{ At least 60 hours } \\
\hline & Coeff. & S.E. & Coeff. & S.E. \\
\hline Debt/income ratio & $0.026^{* *}$ & 0.009 & $0.039 * *$ & 0.009 \\
\hline Debt/income-squared (x 100) & -0.025 & 0.009 & -0.035 & 0.009 \\
\hline No debt & -0.083 & 0.067 & -0.037 & 0.079 \\
\hline Diploma & $-0.232 * *$ & 0.079 & -0.101 & 0.095 \\
\hline Certificate & $-0.253 * *$ & 0.068 & -0.093 & 0.081 \\
\hline Year 12 school & $-0.333^{* *}$ & 0.087 & -0.142 & 0.107 \\
\hline Less than Year 12 & $-0.311 * *$ & 0.077 & -0.109 & 0.091 \\
\hline Manager & $0.967 * *$ & 0.117 & $0.750 *$ & 0.140 \\
\hline Professional & $0.513^{* *}$ & 0.116 & $0.405^{*}$ & 0.144 \\
\hline Promotion & $0.279 * *$ & 0.060 & 0.251 & 0.074 \\
\hline Cost-of-job-loss & $0.191 * *$ & 0.072 & 0.160 & 0.009 \\
\hline Flexibility & 0.075 & 0.051 & 0.131 & 0.065 \\
\hline Male & $0.374^{* *}$ & 0.095 & $0.256^{*}$ & 0.118 \\
\hline Married man & $0.190 * *$ & 0.073 & 0.145 & 0.087 \\
\hline Married woman & -0.036 & 0.087 & -0.033 & 0.114 \\
\hline Mother young child & $-0.585^{* *}$ & 0.142 & $-0.515 * *$ & 0.199 \\
\hline Mother older child & $-0.361^{* *}$ & 0.083 & $-0.419 * *$ & 0.110 \\
\hline Father young child & -0.051 & 0.071 & 0.042 & 0.081 \\
\hline Father older child & 0.048 & 0.062 & 0.019 & 0.069 \\
\hline Age & $0.052 * *$ & 0.013 & $0.063^{* *}$ & 0.015 \\
\hline Age-sq (x 100) & $-0.064 * *$ & 0.015 & $-0.070 * *$ & 0.017 \\
\hline Union member & 0.056 & 0.050 & -0.010 & 0.060 \\
\hline Casual & $-0.701^{* *}$ & 0.096 & $-0.474 * *$ & 0.124 \\
\hline Family income (x 1000) & -0.002 & 0.001 & -0.001 & 0.001 \\
\hline Men x Family income (x 1000) & 0.002 & 0.001 & 0.002 & 0.001 \\
\hline Moonlighting & $0.383^{* *}$ & 0.071 & $0.432 * *$ & 0.080 \\
\hline Buying home & 0.099 & 0.053 & 0.032 & 0.063 \\
\hline Renting & 0.096 & 0.067 & $0.203^{*}$ & 0.079 \\
\hline Free-board & $0.347 *$ & 0.160 & $0.438 * *$ & 0.166 \\
\hline Aboriginal & -0.057 & 0.346 & -0.101 & 0.440 \\
\hline ImmESB & -0.136 & 0.133 & -0.081 & 0.172 \\
\hline ImmNESB & 0.140 & 0.112 & -0.205 & 0.170 \\
\hline AboriginalM & -0.598 & 0.490 & -0.901 & 0.774 \\
\hline ImmESBM & 0.161 & 0.154 & 0.066 & 0.193 \\
\hline ImmNESBM & $-0.373 * *$ & 0.141 & 0.092 & 0.198 \\
\hline Inner-regional & 0.091 & 0.050 & $0.237^{* *}$ & 0.059 \\
\hline Outer-regional & $0.198 * *$ & 0.074 & $0.318^{* *}$ & 0.084 \\
\hline Remote & 0.202 & 0.152 & $0.339 *$ & 0.159 \\
\hline Self-employed & $0.635^{* *}$ & 0.077 & $0.771^{* *}$ & 0.091 \\
\hline Public sector & $-0.302 * *$ & 0.075 & -0.136 & 0.092 \\
\hline Chi-squared & \multicolumn{2}{|c|}{$1458.68^{* *}$} & \multicolumn{2}{|c|}{ 1039.38* } \\
\hline Cragg-Uhler Pseudo-R-squared & \multicolumn{2}{|c|}{.342} & \multicolumn{2}{|c|}{.300} \\
\hline $\mathrm{N}$ & \multicolumn{2}{|c|}{4110} & \multicolumn{2}{|c|}{4110} \\
\hline
\end{tabular}

Notes: Sample consists of all persons employed across Waves 1 through 3 with the same employer.

* Statistically significant at the .05 level; ** at the .01 level. 


\section{Notes}

${ }^{1}$ According to OECD data for 2004, the rate of part-time employment in Australia (27\%) is more than double that in the US (OECD 2005, p. 254). Strictly speaking, these rates are not comparable since they are based on different definitions. The HILDA Survey data used in this paper, however, suggest that when a like definition is used, the part-time employment in Australia is still very high - almost 26 percent compared with 13 percent in the US.

${ }^{2}$ A job tenure variable was also considered, but never achieved significance when entered linearly or as a quadratic. If we were predicting a full range of hours (instead of just long hours), the variable would probably be of greater importance.

${ }^{3}$ The reasons for predicting a negative union effect are somewhat distinct from those relevant to the U.S. In the U.S. collective bargaining may serve to protect employees against long hours, particularly as defined here (i.e., beyond 50 or 60 hours per week). In Australia, however, unions are arguably still adapting to the new decentralized environment, so may not be particularly strong in many individual workplaces. Nonetheless, the central Australian trade union body has waged an on-going campaign against long hours, leading us to predict a negative effect. For information on the "Reasonable Hours" campaign, see www.actu.asn.au.

${ }^{4}$ The total number of respondents in each wave is greater than this for at least three reasons. First, some non-respondents in wave 1 are successfully interviewed in later waves. Second, interviews are sought in later waves with all persons who turn 15 years of age. Third, additional persons are added to the sample (mostly on a temporary basis) as a result of changes in household composition (interviews are sought will all persons who live with a sample member even if they were not part of the original sample). In this paper, however, we only use data from persons who responded in all three waves.

${ }^{5}$ Specifically, the survey asked: "Including any paid or unpaid overtime, how many hours per week do you usually work in all your jobs?”

${ }^{6}$ Note that using the balanced sample appears to introduce very little bias. In the full wave 1 cross-section the proportion of employed persons working 50 hours or more per week is very similar - 22.5\%.

${ }^{7}$ Family income for individuals reporting zero or negative income was set to $\$ 1$ for the debt/income ratio (otherwise these individuals appear to have very low values). The ratio was top-coded at 100 (arguably an extreme value itself) because of a small number of cases, mostly low income households, where the debt to income ratio was extremely high.

${ }^{8}$ The self-employed were not asked to respond to the cost-of-job-loss or flexibility items. These missing values were set as if the self-employment probability of obtaining a similar job was unity and as if the self-employed have scheduling flexibility. It is easy to imagine cases where these imputed values are incorrect; for example, a self-employed individual providing a highly specialized service might find it near impossible to obtain a similar job in the event of bankruptcy, or a self-employed shopowner might need to be present during fixed hours of the day. However, even if our imputed values are incorrect, these would only alter the coefficient of the self-employed variable, and not any results for either the cost-of-job-loss or flexibility variables.

${ }^{9}$ This restriction makes our balanced panel for the persistence analysis comparable to the sample for the cross-sectional analysis.

${ }^{10}$ We considered survival, hazard and fixed-effects models before arriving at the ordered probit. The prior have the advantage of using wave-specific information sequentially, as in 
Table 1. However, these models would be better for identifying reasons for changing hours status (i.e., either movement toward or away from long hours), and not for understanding persistence per se. Given we count waves of long hours, a Poisson model is a relevant alternative to the ordered probit. However, the underlying continuity of hours fits better with the ordered probit model (the Poisson model assumes non-convexity in the phenomenon), and is preferred to the Poisson model when there are many zeroes in the observed dependent variable (Cameron and Trivedi 1998: 85), as is the case here.

${ }^{11}$ Results available in an optional appendix from the authors.

${ }^{12}$ Specifically, in the persistence ordered probits with extensive occupational controls, innerregional and outer-regional patterns of significance remain, but the coefficients consistently decline, while the remote coefficients decline and lose significance at conventional levels.

${ }^{13}$ These include generalist managers, specialist managers, farmers and farm managers, and managers not elsewhere classified.

${ }^{14}$ Note that we cannot distinguish pure occupational effects, perhaps attributable to occupation-specific technologies, or to high capital/labor ratios from the effects of the ideal worker norm. Specifically, if any job in a specific occupation requires long hours for whatever reason, then it might well be the case that finding other jobs is relatively easy because jobs within the occupation are universally demanding. However, in discussions of part-time professional careers, Williams (1999: 72-75), Blair-Loy (2004: 91-93), and Moen and Roehling (2004: 175-176), all argue that it is the beliefs of managers (and related marginalization of part-time employees), rather than technology or the nature of the job, that limits the effective availability of part-time employment, consistent with the ideal worker norm. 


\section{References}

Bailyn, Lotte. 1993. Breaking the Mold. New York: Free Press.

Barnett, Rosalind C. 1998. "Towards a Review and Reconceptualization of the Work/Family Literature.” Genetic, Social, and General Psychology Monographs, Vol. 124, No. 2 (May), pp. 125-183.

and Caryl Rivers. 2004. Same Difference: How Gender Myths Are Hurting Our Relationships, Our Children, and Our Jobs. New York: Basic Books.

Berg, Peter, Eileen Appelbaum, Tom Bailey, and Arne L. Kalleberg. 2004. "Contesting Time: International Comparisons of Employee Control of Working Time.” Industrial and Labor Relations Review, Vol. 57, No. 3 (April), pp. 331-349.

Bianchi, Suzanne M., Melissa Milkie, Liana Sayer, and John Robinson. 2000. "Is Anyone Doing the Housework? Trends in the Gender Division of Household Labor." Social Forces, Vol. 79, No. 1 (September), pp. 191-228.

Blair-Loy, Mary. 2003. Competing Devotions: Career and Family Among Women Executives. Cambridge MA: Harvard University Press.

Bowles, Samuel. 1985. “The Production Process in a Competitive Economy: Walrasian, NeoHobbesian, and Marxian Models.” American Economic Review, Vol. 75, No. 1 (March), pp. 16-36.

Cameron, A. Colin and Pravin K. Trivedi. 1998. Regression Analysis of Count Data. Cambridge UK: Cambridge University Press.

Campbell, Ian. 1996. “Casual Employment, Labour Regulation and Australian Trade Unions.” The Journal of Industrial Relations, Vol. 38, No. 4 (December), pp. 571-599.

Davis, Edward M., and Russell D. Lansbury. 1998. “Employment Relations in Australia.” In Greg J. Bamber and Russell D. Lansbury, eds., International and Comparative Employment Relations. London: Sage.

Drago, Robert, Robert Caplan, David Costanza, Tanya Brubaker, Darnell Cloud, Naomi Harris, Russell Kashian and T. Lynn Riggs. 1999. "New Estimates of Working Time for Teachers.” Monthly Labor Review, Vol. 122, No. 4 (April), pp. 31-41.

Golden, Lonnie. 2001. “Flexible Work Schedules: What Are We Trading Off to Get Them?” Monthly Labor Review, Vol. 124, No. 3 (March), pp. 50-67. 
Hamermesh, Daniel. 1996. Workdays, Workhours, and Work Schedules: Evidence for the United States and Germany. Kalamazoo MI: W.E. Upjohn Institute.

Harkness, Susan. 1999. “Working 9 to 5?” In Paul Gregg and Jonathan Wadsworth, eds., The State of Working Britain. Manchester: Manchester University Press.

Hochschild, Arlie. 1997. The Time Bind: When Work Becomes Home and Home Becomes Work. New York: Metropolitan Books.

Headey, Bruce and Mark Wooden. 2005. "Income, Wealth and Joblessness: Insights from the HILDA Survey”. In Peter Dawkins and Michael Stutchbury, eds., Sustaining Prosperity. Melbourne: Melbourne University Press.

Jacobs, Jerry and Kathleen Gerson. 2000. “Who Are the Overworked Americans?” In Lonnie Golden and Deborah Figart, eds., Working Time: International Trends, Theory and Policy Perspectives. London: Routledge. . and . 2004. The Time Divide: Work, Family and Gender Inequality. Cambridge MA: Harvard University Press.

Killingsworth, Mark. 1993. Labor Supply. Cambridge England: Cambridge University Press. Landers, Renee M., Rebitzer, James B. and Lowell J. Taylor. 1996. "Rat Race Redux: Adverse Selection in the Determination of Work Hours in Law Firms." American Economic Review, Vol. 86, No. 3 (June), pp. 329-348.

Lee, Yun-Suk and Linda J. Waite. 2005. “Husbands' and Wives’ Time Spent on Housework: A Comparison of Measures.” Journal of Marriage and Family, Vol. 67, No. 2 (May), pp. 328-336.

Manski, Charles F. and John D. Straub. 2000. "Worker Perceptions of Job Insecurity in the Mid-1990s”. The Journal of Human Resources, Vol. 35, No. 3 (Summer), pp. 447-479.

Moen, Phyllis, and Patricia Roehling. 2004. The Career Mystique: Cracks in the American Dream. Lanham, MD: Rowman \& Littlefield.

Nock, Steven and Paul William Kingston. 1988. "Time with Children: The Impact of Couples’ Work-Time Commitments.” Social Forces, Vol. 67, No. 1 (September), pp. 5985.

Organisation for Economic Cooperation and Development (OECD). 2005. OECD Employment Outlook 2005. Paris: OECD. 
Sandberg, John and Hofferth, Sandra L. 2001. “Changes in Children’s Time with Parents, U.S., 1981-1997.” In Timothy J. Owens and Sandra L. Hofferth, eds., Children at the Millenium: Advances in Life Course Research. New York: Elsevier.

Schor, Juliet. 1991. The Overworked American: The Unexpected Decline of Leisure. New York: Basic Books. 1999. The Overspent American: Why We Want What We Don't Need. New York: Perennial.

Sparks, Kate, Cary Cooper, Yitzhak Fried and Arie Shirom. 1997. "The Effects of Hours of Work on Health: A Meta-analytic Review.” Journal of Occupational and Organizational Psychology, Vol. 70, No. 4 (December), pp. 391-408.

Watson, Nicole and Mark Wooden. 2004. "The HILDA Survey Four Years On.” The Australian Economic Review, Vol. 37, No. 3 (September), pp. 343-349.

Williams, Joan. 1999. Unbending Gender: Why Work and Family Conflict and What To Do About It. New York: Oxford University Press.

Wooden, Mark. 2000. The Transformation of Australian Industrial Relations. Sydney: The Federation Press. 2001. “The Growth in 'Unpaid’ Working Time.” Economic Papers, Vol. 20, No. 3 (September), pp. 29-44. 